\title{
Iatrogenic vocal process fracture and arytenoid dislocation caused by transesophageal echocardiography
}

\author{
Transözofageal ekokardiyografinin neden olduğu iyatrojenik vokal proses kırı̆̆ı ve \\ aritenoid dislokasyonu
}

Adem Binnetoğlu, Tekin Bağlam, Ali Cemal Yumuşakhuylu, Melis Demirağ Evman,

Berat Demir, Murat Sarı

Department of Otolaryngology, Marmara University Pendik Training and Research Hospital, İstanbul, Turkey

\begin{abstract}
Arytenoid dislocation (AD) is a rare condition that may occur secondary to laryngeal trauma. Fiberoptic laryngoscopy, laryngeal computed tomography, and laryngeal electromyography are used to diagnose vocal process fracture in conjunction with AD. In this article, we report a 26-yearold female patient with hoarseness after transesophageal echocardiography. With the diagnosis of concomitant AD and vocal process fracture, closed reduction was performed. Closed reduction should be considered for all patients in whom instruments have been used in the upper aerodigestive tract and particularly who are diagnosed as AD and non-responsive to reduction procedures.
\end{abstract}

Keywords: Arytenoid dislocation; arytenoid subluxation; intubation trauma; vocal cord movement; voice recovery.

Arytenoid dislocation (AD) is a rare condition that can occur secondary to blunt trauma or during instrument use in the upper aerodigestive tract. ${ }^{[1]}$ The overall incidence of AD is unknown, but it is reported to occur in $0.1 \%$ of cases of endotracheal intubation. ${ }^{[2]}$ To the best of our knowledge, vocal process (VP) fracture in conjunction with $\mathrm{AD}$ has not been reported previously in the English literature. Herein we report a unique case of VP fracture accompanying AD.
$\ddot{O} Z$

Aritenoid dislokasyonu (AD) larengeal travmaya sekonder gelişebilen nadir bir durumdur. Aritenoid dislokasyonu ile birlikte olan vokal proses kırığına tanı koymak için fiberoptik larengoskopi, larengeal bilgisayarlı tomografi ve larengeal elektromiyografi kullanılır. Bu yazıda, transözofageal ekokardiyografiden sonra ses kısıklığ olan 26 yaşında bir kadın hasta sunuldu. Eşlik eden AD ve vokal proses kırığı tanısıyla kapalı redüksiyon uyguland. Üst solunum yolu ve sindirim sisteminde enstrüman kullanılan ve özellikle $A D$ tanısı konulup redüksiyon işlemlerine yanıt vermeyen tüm hastalarda kapalı redüksiyon düşünülmelidir.

Anahtar sözcükler: Aritenoid dislokasyonu; aritenoid sublüksasyonu; entübasyon travması; vokal kord hareketi; ses iyileşmesi.

\section{CASE REPORT}

A 26-year-old woman was admitted to our outpatient clinic with hoarseness, two days after transesophageal echocardiography (TEE) for cardiac mitral valve failure. There was no history of smoking, alcohol use or any other contributory risk factors for laryngeal carcinoma. There was no renal disease, inflammatory bowel disease, rheumatoid arthritis, acromegaly or steroid administration as a predisposing factor for cricoarytenoid 

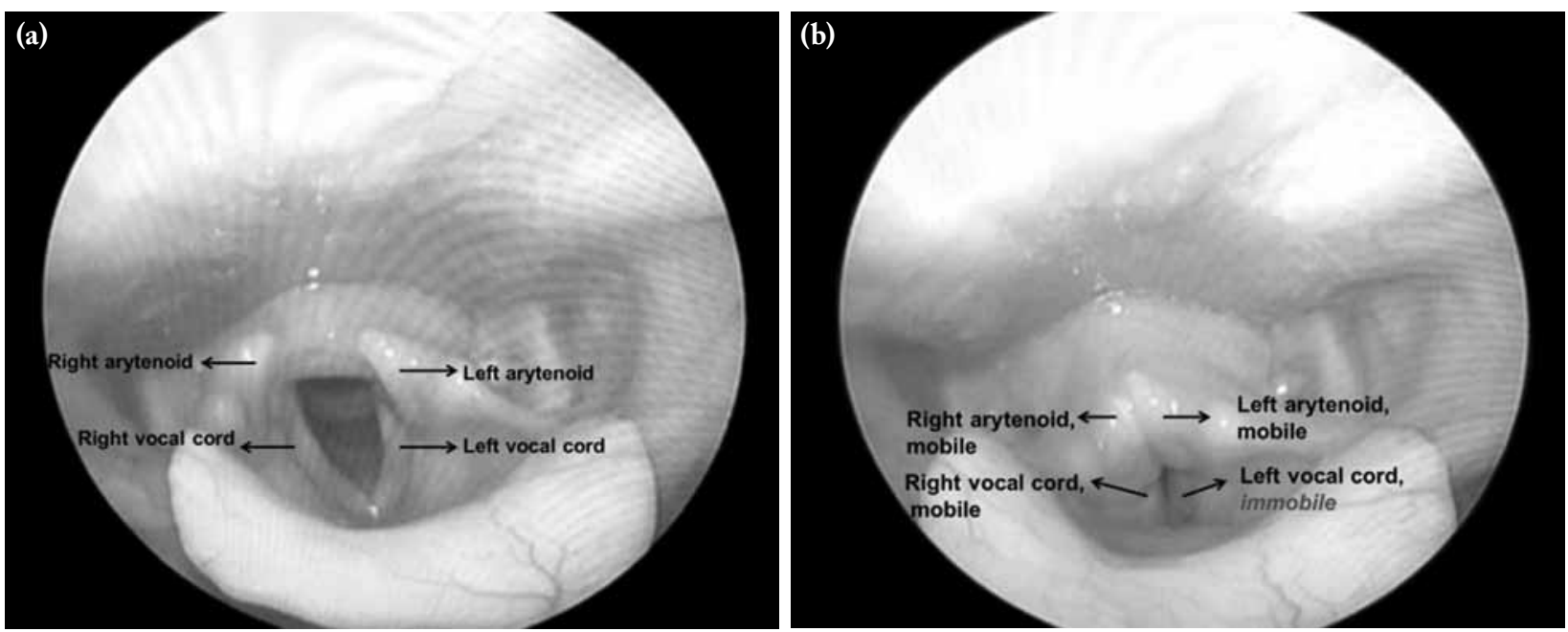

Figure 1. (a) Fiberoptic laryngoscopic examination showing posteromedial displacement of the left arytenoid cartilage and impaired vocal cord abduction during inspiration. (b) Fiberoptic laryngoscopic examination showing mobile left arytenoid cartilage but immobile left vocal process during glottic closure.

joint laxity. The patient had no symptoms of dysphagia, odynophagia or stridor. Fiberoptic laryngoscopy revealed the left arytenoid was mobile during glottic closure, but the left VP was not (Figure 1a, b). In consideration of discordance between arytenoid and VP mobility, we focused on diagnosing a probable VP fracture. Axial computed tomography (CT) of the larynx showed a tiny fracture of the left VP tip where the vocal ligament attaches, posteromedial displacement of the left arytenoid cartilage and widening of the laryngeal vestibule, called a "Sail Sign" radiologically (Figure 2a, b). With the concomitant diagnosis of VP fracture and $\mathrm{AD}$, we performed direct laryngoscopy under jet ventilation without endotracheal intubation. Direct laryngoscopic examination showed the left arytenoid was mobile and dislocated posteromedially, whereas the left VP was completely immobile. We performed closed reduction by rotating the left arytenoid anteromedially using a spatula (Figure 3). After closed reduction, joint stability assessment showed the arytenoid was repositioned to its normal location but the left VP was still immobile. The continued discordance between arytenoid and VP mobility even after closed arytenoid reduction further confirmed the diagnosis of concomitant VP fracture. A written informed consent was obtained from the patient.

\section{DISCUSSION}

Arytenoid dislocation is a rare clinical entity first described by Korman et al. ${ }^{[3]}$ in 1973. Kambic and Radsel $^{[4]}$ reported in their prospective study that AD occur in $0.1 \%$ of cases of endotracheal intubation. However, the true incidence of $\mathrm{AD}$ is greater than
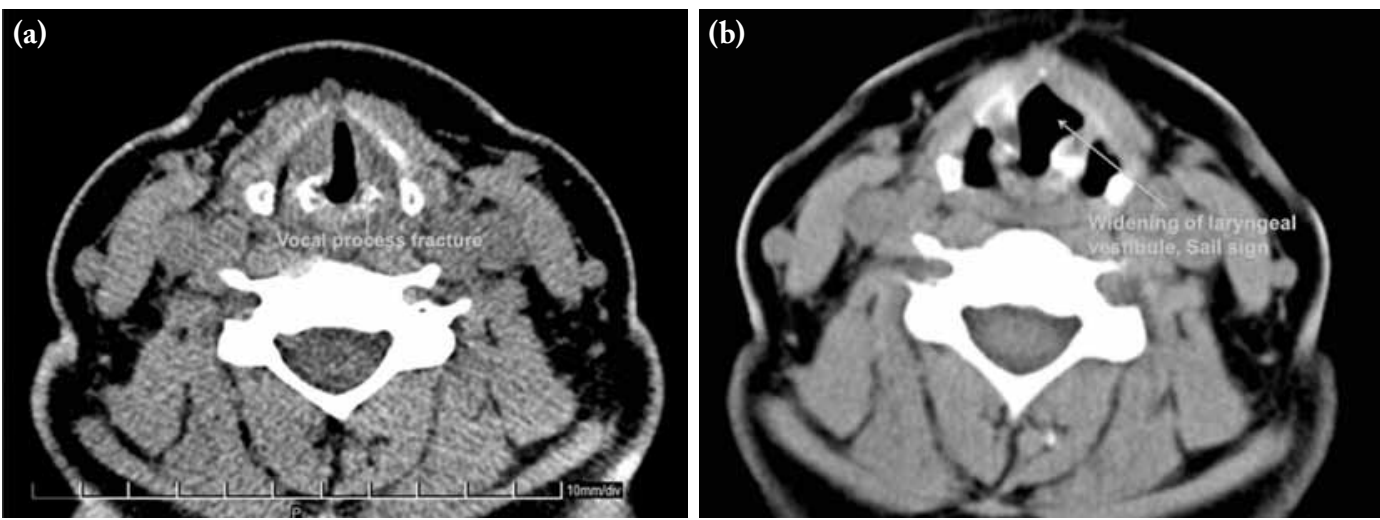

Figure 2. (a) Axial computed tomography scan reveals a tiny fracture of the left vocal process tip. (b) Axial computed tomography scan reveals posteromedial displacement of left arytenoid cartilage and widening of laryngeal vestibule (Sail Sign). 


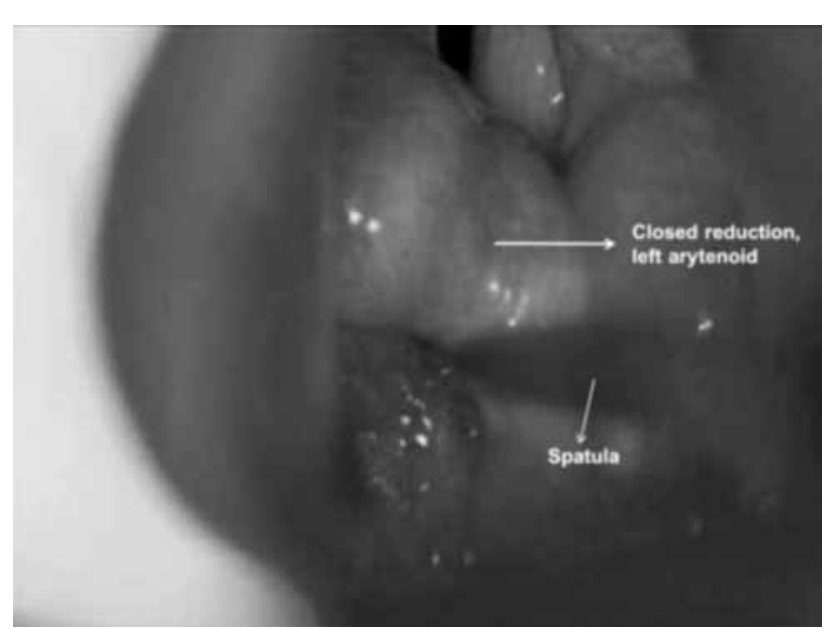

Figure 3. Closed reduction procedure, rotating the left arytenoid anteromedially with the spatula.

reported because most $\mathrm{AD}$ cases are misdiagnosed as vocal cord paralysis. ${ }^{[5]}$ The most common etiologic factor of $\mathrm{AD}$ is intubation trauma, followed by external laryngeal trauma. ${ }^{[6]}$ Other etiologic factors of $\mathrm{AD}$ are laryngeal mask use, upper gastrointestinal endoscopy, lighted stylet trauma, McCoy laryngoscope and double lumen tube injury, blind instrumentation of the esophagus with a rigid nasogastric tube and transesophageal echocardiogram probe as well as challenging intubation. ${ }^{[7]}$

Although AD alone has been reported previously, we could find no data on VP fracture accompanying AD as found in our unique case. It has been speculated that there are some risk factors making the joint susceptible to traumatic dislocation including renal disease, inflammatory bowel disease, rheumatoid arthritis, acromegaly and chronic steroid administration. ${ }^{[8]}$ In the present case, the insertion of the TEE probe was the cause of VP fracture accompanying AD. Patients with AD usually manifested by hoarseness, dysphagia, aspiration, odynophagia, and respiratory stridor. ${ }^{[9]}$ In our case the presenting symptom was the only hoarseness after the TEE procedure. Detailed history and complete physical examination are necessary. Diagnosis is usually made by using fiberoptic laryngoscopy. ${ }^{[9]}$ But other diagnostic tests are CT scanning and laryngeal electromyography (EMG). Fiberoptic laryngoscopic findings suggestive of $\mathrm{AD}$ include reduced vocal fold mobility, arytenoid swelling due to edema, presence of arytenoid asymmetry, absence of vocal fold lengthening with increased pitch, abnormal vocal fold length, and VP level difference. Arytenoid dislocation direction is also important for planning of correct reduction. Posterior dislocations result in a high and laterally displaced VP and a stretched vocal fold, but anterior dislocations result usually in a low VP and a short, lax vocal fold. ${ }^{[6]}$ In our present case, fiberoptic laryngoscopic examination showed the left arytenoid was mobile and dislocated posteromedially, whereas left VP was completely immobile. In consideration of discordance between arytenoid and VP mobility, the presence of VP fracture was suspected. A CT scan could be a helpful adjunctive diagnostic tool. A positive CT scan is crucial to verify the diagnosis, but a negative scan does not rule out $\mathrm{AD}$ dislocation. Alexander et al. ${ }^{[10]}$ demonstrated that CT scans did not show arytenoid asymmetry in $18 \%$ of patients where abnormalities of the cricoarytenoid joint were seen on laryngoscopy. Computed tomography scan findings, suggestive of $\mathrm{AD}$, include anterior- or posterior-positioned arytenoid, asymmetric localization of VP and/or joint space, obliteration or widening of the joint space, and dilated ipsilateral laryngeal ventricle -also known as the "Sail Sign". ${ }^{[6]}$ In the present case axial CT scan of the larynx showed a tiny fracture of the left VP tip where the vocal ligament attaches, posteromedial displacement of left arytenoid cartilage and widening of laryngeal vestibule (Sail Sign) (Figure 2a, b). Considering all the fiberoptic larygoscopic and $\mathrm{CT}$ scan findings together, the diagnosis was $\mathrm{AD}$ with concomitant VP fracture. Laryngeal EMG is also helpful in diagnosis of AD..$^{[6,11,12]}$ Rubin et al. ${ }^{[6]}$ demonstrated that laryngeal EMG showed abnormalities in 25 of 45 patients (55.6\%). The pattern of EMG recorded in AD is generally that of normal recruitment. ${ }^{[13]}$ Other less common EMG patterns include myopathy and reinnervation potentials. ${ }^{[13]}$ Patterns like fibrillation potentials or absence of electrical activity are usually associated with recurrent laryngeal nerve paralysis. ${ }^{[11]}$ Thus, laryngeal EMG is also important in distinguishing $\mathrm{AD}$ from vocal fold paralysis. Treatment methods for $\mathrm{AD}$ include spontaneous resolution, closed reduction through direct or indirect laryngoscopy and speech therapy. ${ }^{[11]}$ Closed reduction of the arytenoid cartilage is an effective treatment method..$^{[9,11,14]}$ With the diagnosis of $\mathrm{AD}$ and concomitant VP fracture, we performed closed reduction by rotating the left arytenoid anteromedially using a spatula (Figure 3). After closed reduction, joint stability was assessed and the arytenoid was repositioned normally, but the left VP was still immobile. The continuation of discordance between arytenoid and VP mobility even after arytenoid reduction further confirmed the diagnosis of concomitant VP fracture. On follow-up, fiberoptic laryngoscopy showed the same discordance between arytenoid and VP mobility. Although we considered injection medialization laryngoplasty with an injectable material, the patient refused because of another planned cardiac operation for mitral valve failure. 
Voice therapy was the only remaining treatment method for this patient. After speech therapy, the patient had only limited voice improvement as we had expected.

Although $\mathrm{AD}$ is a rare disease, VP fracture in conjunction with $\mathrm{AD}$ has not been reported previously. The incidence of VP fracture in conjunction with $\mathrm{AD}$ or alone is greater than published in the literature because most VP fracture cases are undiagnosed or misdiagnosed as vocal cord paralysis or AD alone.

Arytenoid dislocation reduction with injection medialization laryngoplasty and/or speech therapy is the rational choice of treatment for AD. A concomitant VP fracture should be considered for all patients who have undergone instrumentation in the upper aerodigestive tract, especially those diagnosed as AD but are nonresponsive to reduction.

\section{Declaration of conflicting interests}

The authors declared no conflicts of interest with respect to the authorship and/or publication of this article.

\section{Funding}

The authors received no financial support for the research and/or authorship of this article.

\section{REFERENCES}

1. Sataloff RT, Bough ID Jr, Spiegel JR. Arytenoid dislocation: diagnosis and treatment. Laryngoscope 1994;104:1353-61.

2. Yamanaka H, Hayashi Y, Watanabe Y, Uematu H, Mashimo T. Prolonged hoarseness and arytenoid cartilage dislocation after tracheal intubation. Br J Anaesth 2009;103:452-5.

3. Komorn RM, Smith CP, Erwin JR. Acute laryngeal injury with short-term endotracheal anesthesia. Laryngoscope 1973;83:683-90.

4. Kambic V, Radsel Z. Intubation lesions of the larynx. Br J Anaesth 1978;50:587-90.

5. Roberts D, McQuinn T, Beckerman RC. Neonatal arytenoid dislocation. Pediatrics 1988;81:580-2.

6. Rubin AD, Hawkshaw MJ, Moyer CA, Dean CM, Sataloff RT. Arytenoid cartilage dislocation: a 20-year experience. Voice 2005;19:687-701.

7. Mallon AS, Portnoy JE, Landrum T, Sataloff RT. Pediatric arytenoid dislocation: diagnosis and treatment. J Voice 2014;28:115-22.

8. Hoffman HT, Brunberg JA, Winter P, Sullivan MJ, Kileny PR. Arytenoid subluxation: diagnosis and treatment. Ann Otol Rhinol Laryngol 1991;100:1-9.

9. Leelamanit $\mathrm{V}$, Sinkijcharoenchai $\mathrm{W}$. A promising new technique for closed reduction of arytenoid dislocation. J Laryngol Otol 2012;126:168-74.

10. Alexander AE Jr, Lyons GD, Fazekas-May MA, Rigby PL, Nuss DW, David L, et al. Utility of helical computed tomography in the study of arytenoid dislocation and arytenoid subluxation. Ann Otol Rhinol Laryngol 1997;106:1020-3.

11. Norris BK, Schweinfurth JM. Arytenoid dislocation: An analysis of the contemporary literature. Laryngoscope 2011;121:142-6.

12. Hiramatsu H, Tokashiki R, Kitamura M, Motohashi R, Tsukahara K, Suzuki M. New approach to diagnose arytenoid dislocation and subluxation using threedimensional computed tomography. Eur Arch Otorhinolaryngol 2010;267:1893-903.

13. Yin SS, Qiu WW, Stucker FJ. Value of electromyography in differential diagnosis of laryngeal joint injuries after intubation. Ann Otol Rhinol Laryngol 1996;105:446-51.

14. Wang Z, Liu Q. A comparative study on the close reduction of arytenoid dislocation under indirect and direct laryngoscope. J Huazhong Univ Sci Technolog Med Sci 2002;22:375-7. 